\title{
FORMAÇÃO DE PROFESSORES DE LÍNGUAS: SABERES, SUJEITOS, POLÍTICAS E CURRÍCULOS
}

Este dossiê temático nasceu do desejo de reunir pesquisas realizadas por diversos estudiosos da área de formação de professores, com as quais estabelecemos diálogos na tentativa de fazer uma leitura e elaborar um panorama dessas investigações. A união destes textos integrados neste volume não está calcada no fato de adotarem a mesma perspectiva teórica, mas o de se interessarem e investigarem a formação de professores de línguas, que é vista em suas diversas perspectivas, tais como: a eficácia de leis, decretos e normas na qualidade da educação; o cotidiano da vida universitária, o letramento, a inclusão, a interculturalidade, as políticas, os currículos entre outras questões da formação inicial e continuada de professores.

Assim, este dossiê ressalta o caráter interdisciplinar desses estudos, que se voltam para a preparação de docentes para a educação básica, os elementos basilares e temáticas que emergem no século XXI, diante da mudança de paradigma educacional e suas repercussões na formação de professores e dos licenciados em Letras, além das transformações na educação básica.

No contexto de sociedades globalizadas, a prática docente séria e crítica deve dialogar através das fronteiras e ser lugar do desenvolvimento paralelo da tradição e da inovação, em que velhos paradigmas são rompidos, velhas teorias deslocadas e uma gama de premissas e temas mobilizados pela realidade.

A sociedade contemporânea é marcada pela grande influência e circulação da informação e comunicação pelo globo, que produzem outras práticas e outros sujeitos. É nesse horizonte que a educação, no âmbito escolar e universitário, ocupa um lugar central na sociedade, como elemento catalizador de saberes acumulados e emergentes. Para tanto, 
há a necessidade de formar profissionais hábeis a trabalhar no diálogo entre as teorias e o complexo contexto da sala de aula.

Diante dessas demandas, pesquisadores têm se debruçado sobre as questões das licenciaturas, dos licenciados e da relação com a prática. São investigações que demonstram o contexto de intensas transformações na sociedade atual e requerem diálogos que transponham os limites das disciplinas, em busca de outras perspectivas teóricometodológicas. Então, é necessário problematizar a realidade e, com ela, dialogar a fim de entender os sujeitos e as práticas, sem se contentar com soluções simplistas e imediatas.

Nesse contexto, segundo Tardif (2002, p. 228), é necessário pensar a formação de professores considerando que eles “[...] possuem saberes específicos que são mobilizados, utilizados e produzidos por eles no âmbito de suas tarefas cotidianas”, isto é, a prática docente é perpassada por um conjunto amplo de saberes e vivências, no qual a educação universitária é um dos elemento. No decorrer da prática docente, o professor produz e se apropria de conhecimentos, experiências e vivências discentes e docentes para se produzir como profissional. Ele transcende o si para uma existência em interação com os outros sujeitos e o espaço para se produzir e elaborar o cotidiano da profissão. Assim, investigar os saberes que são articulados na prática do ensinar significa se aproximar do processo de ensino-aprendizagem.

Nessa mesma direção, Castro (2006, p. 293) afirma que a prática docente prescinde da forte ligação ente a teoria aprendida na universidade e a prática no cotidiano escolar para romper com "[...] o descompasso entre as ações desses profissionais e as singulares e complexas situações de ensino e aprendizagem do cotidiano da sala de aula". Nesse horizonte, vários estudiosos brasileiros, a exemplo de Pimenta (2002), insistem que é urgente que os cursos de formação inicial estimulem as experiências docentes do alunoprofessor como forma de estimular a capacidade de reflexão de sua prática constantemente, desde o início do curso. Portanto, a prática docente precisa estar amparada na união de diversos conhecimentos, "adquiridos através de certos processos de aprendizagem e de 
socialização que atravessam tanto a história de vida quanto a carreira" (TARDIF; RAYMOND, 2000, p. 234).

Ainda pensando o fazer docente, Libâneo e Pimenta (1999, p. 267) vaticinam que:

As investigações recentes sobre formação de professores apontam como questão essencial o fato de que os professores desempenham uma atividade teórico-prática. É difícil pensar na possibilidade de educar fora de uma situação concreta e de uma realidade definida. A profissão de professor precisa combinar sistematicamente elementos teóricos com situações práticas reais.

Entretanto, Gatti (2014), por meio de pesquisas estatísticas, ressalta que os cursos de licenciatura no Brasil apresentam uma formação focada em conhecimentos pedagógicos, estanques, com a predominância do conhecimento específico, deixando pouco espaço para a questões da escola, da aprendizagem escolar, com um perfil muito abstrato e disciplinar para os sujeitos egressos. E faz o vocativo de que "[...] seria desejável se o trabalho real dos profissionais fossem referência para sua formação.” (GATTI, 2014, p. 39).

Assim, parece haver uma inversão no movimento escola-universidade, ao invés de os cursos de licenciatura prepararem professores tendo em mente as necessidades da escola, mostram-se as teorias acadêmicas como balizadora da realidade. Contudo, as teorias, por si só, não têm garantido a prática profissional, com os desafios e os impasses do ensinar. O cotidiano escolar está sempre se reinventando em uma dinâmica bem diferente daquela dos conhecimentos enciclopédicos.

Especificamente sobre o profissional de Letras, Leffa (2001, p. 340) destaca, que “achar que um profissional de letras possa ser formado nos bancos da universidade é uma ilusão, necessária ou não (será necessária na medida em que o professor formador vai precisar dessa ilusão para dar continuidade ao seu trabalho)". Isso aponta a formação como um processo contínua em que o aluno-professor é o ponto onde se encontram seu conhecimento como estudante, seu conhecimento como licenciado e seu conhecimento como profissional, de maneira que a exposição ao cotidiano escolar vai movimentar e atualizar a prática profissional. 
Retomamos Gatti (2014) ao afirmar que os cursos de licenciatura são responsáveis apenas por aprendizagens iniciais e básicas do sujeito professor, assumindo como central a incompletude do sujeito em si e da realidade. Em outros termos, a formação acadêmica representa os conhecimentos basilares a serem mobilizados na prática cotidiana.

Nesse contexto, a formação de professores precisa sofrer mudanças revolucionárias no que diz respeito, igualmente, à sua dinâmica curricular e estruturas formativas, pois “[a]s emendas já são muitas. A fragmentação formativa é clara” (GATTI, 2010, p. 1375). Faz-se necessário, portanto, elaborar currículos que proponham a formação de professores considerando a função social própria da escolarização, enquanto ensino voltado para promoção da equidade social e da justiça.

Todavia, Gatti (2010) considera que as iniciativas voltadas para inovação nas estruturas dos cursos de formação de professor encontram várias barreiras em repensar e reestruturar essa formação, pelo fato de se esbarrarem nos pressupostos tradicionais e nos interesses já instituídos.

A respeito das relações de conflitos e de interesses das instituições de ensino, Contreras (2012, p. 168) aponta a disputa entre os princípios educativos e a percepção de ensino ensimesmada na escola, quando diz que "[e]nquanto, por um lado, se formulam as finalidades educativas como formas de preparação para uma vida adulta com capacidade crítica em uma sociedade plural, por outro lado a docência e a vida na escola se estruturam negando essas pretensões.” Essas relações evidenciam que a escolarização é um processo atravessado por questões políticas, econômicas e culturais que produzem as instituições de ensino.

É importante que a formação de professores seja pensada como uma prática acadêmica, mas antes de tudo como lugar de relações políticas que tecem nossa sociedade e nossas instituições. De mesmo modo, é imprescindível dar condições para os alunosprofessores refletirem e se posicionarem diante da sua realidade acadêmica e profissional. Nas palavras de Contreras (2012, p. 173-174), 
Conceber o trabalho dos professores como trabalho intelectual quer dizer, portanto, desenvolver um conhecimento sobre o ensino que reconheça e questione sua natureza socialmente construída e o modo pelo qual se relaciona com a ordem social, bem como analisar as possibilidades transformadoras implícitas no contexto social das aulas e do ensino.

Foi a partir desse cenário que pesquisadores de várias regiões do Brasil aceitaram o nosso convite a refletirem sobre a formação de professores de línguas para este dossiê temático. Com o objetivo de abordar o tema do dossiê, os pesquisadores envolvidos observaram que a atualidade brasileira evidencia (re)configurações da prática docente, tanto na academia como na escola, aspecto merecedor de estudos e investigações. Com esse objetivo, os artigos aqui reunidos abordam diferentes facetas do processo de formação de licenciados em Letras e focalizam, igualmente, movimentos de reivindicação por reconhecimento e pertencimento social. Além da problemática das mudanças nos paradigmas educacionais, outras reflexões emergiram que ora apresentamos.

Assumindo a premissa da língua inglesa como língua global falada por diferentes povos em todo o mundo e meio de comunicação em variados contextos e para fins diversos, os autores Claudia Bittencourt Pereira e Diógenes Cândido de Lima discutem seu papel no âmbito das relações comerciais em "A língua inglesa e as relações comerciais: elementos e reflexões”. A partir de relatos de profissionais da área de negócios, eles asseveram que investir na aprendizagem do inglês pode influenciar positivamente nos resultados das atividades comerciais, bem como impulsionar o mercado de trabalho.

Em “A Linguística Cognitiva na sala de aula: encaminhamentos possíveis", Dedilene Alves de Jesus toma como mote conceitos cognitivistas para pensar contribuições direcionadas a práticas docentes e práticas de ensino e de aprendizagem. Tal percurso pela Linguística Cognitiva mostra ferramentas viáveis para a análise de práticas pedagógicas em sala de aula a partir da linguagem. Após levantar cinco questões-argumento - como realizar estudos de Linguística Cognitiva em sala de aula; que tipo de aula pode ser analisada seguindo seus conceitos; que bases de análise utilizar na apresentação de uma situação de aula em que um aluno não compreende os conceitos apresentados pelo professor; que 
objetos de pesquisa podem ser considerados para uma análise eficaz pela por essa subárea; e esse tipo de análise é realmente produtivo. Então, argumenta que todas as vertentes teóricas podem contribuir com a sala de aula; que as tecnologias impõem abordagens focadas nas linguagens; que a Linguística Cognitiva pode oferecer subsídios para o desenvolvimento das habilidades de leitura, escrita, fala e escuta; e, por fim, que os processos de ensino e aprendizagem são multifacetados e essa subárea pode contribuir.

No terceiro artigo, "Formação inicial do professor de língua inglesa: multiletramentos e construção de sentidos em ambientes virtuais", Ilza Leia Ramos Arouche e Dorotea Frank Kersch destacam como a sociedade contemporânea exige novas competências, a exemplo dos letramentos digitais. O objetivo é discutir como a pedagogia dos multiletramentos pode contribuir para a construção de sentidos. O estudo mostra que a abordagem de temas transversais com o uso de ferramentas digitais pode ser um caminho para propiciar o letramento digital, favorecer a aprendizagem colaborativa e desenvolver a expressão escrita em língua inglesa.

Ainda abordando a importância do letramento, o estudo "Oralidade, leitura, escrita e formação de professores: tecendo reflexões" apresenta uma reflexão de docentes licenciatura em língua portuguesa sobre oralidade, leitura, escrita e letramento. A partir de experiências em projetos vinculados ao Programa Institucional de Bolsas de Iniciação à Docência, Ângela Cogo Fronckowiak, Carlos René Ayres e Cristiane Dall Cortivo Lebler afirmam a necessidade de políticas públicas para educação que promovam o estreitamento da relação entre teoria e prática, entre universidade, escolas e sociedade para a efetividade do letramento para o mundo.

No texto "O lugar dos estudos de língua e literatura latina na formação do professor de português", Grace Freire Bandeira discute o lugar dos estudos dessa língua e literatura na formação do professor de língua portuguesa. Ela reflete a partir dos Parâmetros Curriculares Nacionais, para pôr em cotejo com experiências que outros países têm nessa área de conhecimento e enfatiza práticas que poderão ser contempladas pelos alunos nos níveis médio e fundamental. 
O artigo "Língua portuguesa para surdos: ações formativas no curso de licenciatura em Letras libras" assume como objetivo analisar como o curso de Licenciatura em Letras com habilitações em português, libras e língua inglesa de uma universidade federal forma docentes surdos e busca atender os alunos surdos para promoção da aprendizagem de língua portuguesa. Para tanto, Lúcia Gracia Ferreira, Lucimar Gracia Ferreira e Lilian Moreira Cruz analisaram o projeto pedagógico do curso para identificar como a libras é apresentada nesse documento, suas ações e desafios. Elas verificaram que esse documento atende às exigências legais, mas apresenta uma lacuna quanto à aprendizagem de língua portuguesa pelos surdos, quando esta habilitação se torna opcional.

Dedicando-se igualmente à formação docente, as autoras Lidia Stutz e Vera Lúcia Lopes Cristovão, em “Autoconfrontação na formação inicial de professores: um instrumento para reconfigurar saberes docentes", visam reconhecer as avaliações, tensões, saberes e capacidades docentes de alunos-professores do curso de Letras língua inglesa diante das experiências realizadas no estágio supervisionado. Com base na percepção de que os saberes sobre o contexto e o papel do professor emergidos em capacidades de autoavaliação e de identificação dos problemas didáticos possibilitam a transformação dos saberes reflexivos, os autores sustentam que a autoavaliação das alunas-professoras é constituída por conhecimentos advindos das experiências do senso comum e por conhecimentos formais.

No artigo "Linguística aplicada, saber glocal e interdisciplinaridade", é apresentada a relação entre Linguística aplicada e interdisciplinaridade a fim de dar conta do saber glocal na sala de aula. Eliana Márcia dos Santos Carvalho conclui que o saber globalizado e o saber especializado são desafios atuais à educação. Ela faz o vocativo para que o conhecimento seja concebido na totalidade das situações e que sejam transgredidos conceitos e disciplinas.

Tratando de outra faceta, a relação entre formação de professor e a utilização das tecnologias é explorada no texto intitulado "Formação inicial e continuada de professor face às tecnologias digitais". Amparados nas noções de discurso, multimodalidade, 
letramento digital e formação de professores, Sandro Luis Silva e Cirlei Izabel da Silva Paiva analisam os Parâmetros Curriculares Nacionais e a Lei de Diretrizes e Bases entre outros documentos e sondam as possibilidades de dois aplicativos. Por fim, eles apontam que é necessária uma articulação entre teoria e prática, de modo a possibilitar uma maior consciência sobre a complexidade do fazer docente. $\mathrm{O}$ uso de aplicativos para a construção do conhecimento na formação pode potencializar a interação entre sujeitos e conhecimento assim como a colaboração e o dinamismo na prática pedagógica.

O texto "Desenvolvimento do letramento em avaliação de línguas a partir de um protocolo de refino de correções" propõe a discutir a noção de letramento em avaliação de línguas, bem como os conceitos-chave validade e confiabilidade, para depois apresentar um protocolo de refino de correção e argumentar como essa prática pode desenvolver o conhecimento por parte dos avaliadores sobre seu comportamento de atribuição de notas às respostas abertas. Laura Márcia Luiza Ferreira conclui que o protocolo de refino de correções pode gerar discussões sobre crenças e compreensão sobre ensinar e aprender línguas.

Em “A construção de conceitos teóricos por meio da prática pedagógica: formação de professores de línguas”, Elisa Novaski Cordeiro e Francisco Carlos Fogaça analisam de que modo a atividade de monitoria voluntária no projeto Português para Falantes de Outras Línguas colaborou com a formação docente no curso de Letras Inglês. A partir dos conceitos de professor reflexivo e articulação de teoria e prática nesses cursos, os autores concluem que a prática propiciada pela participação dos discentes no projeto de extensão teve boa repercussão no preparo dos licenciandos e lhes possibilitou a efetiva articulação entre teoria e prática.

No texto "Biblioteca e salas de leitura: espaços de mediação leitora na formação docente", Deisi Luzia Zanatta e Fabiane Verardi apresentam e discutem a função da biblioteca e das salas de leitura na formação inicial dos discentes dos cursos de Letras e de Pedagogia de três universidades brasileiras. Eles observam que as salas de leitura precisam se tornar espaços de ações leitoras na formação inicial desses futuros professores para que 
possam assumir essa prática no exercício profissional. Nesse sentido, elaboram uma proposta para fortalecer esse elo entre os licenciandos, as atividades de leitura e o espaço da biblioteca.

Sob o título "Saberes necessários ao professor para avaliar a aprendizagem de crianças na sala de aula de línguas estrangeiras", Juliana Reichert Assunção Tonelli e Gladys Quevedo-Camargo destacam o crescimento do ensino de línguas estrangeiras para crianças e propõe uma discussão em torno do letramento em avaliação do professor. A partir de questionário respondido por docentes, as pesquisadoras chegaram à conclusão de que os participantes não têm propriedade sobre o uso de avaliação para guiar os objetivos do ensino ou da aprendizagem, para avaliar o progresso na aprendizagem de línguas; para diagnosticar os pontos fortes e fracos dos alunos e para motivar a aprendizagem dos alunos.

Focalizando a importância da leitura, Patrícia Cardoso Batista e Sheila Oliveira Lima, autoras de "O professor de língua portuguesa e sua história com a leitura", apresentam histórias de professoras de língua portuguesa na vivência da leitura, a fim de tecer uma reflexão sobre sua própria relação com a leitura. Fundamentados por um estudo de caso, os autores concluem que a leitura envolve uma mediação envolta em afetividade, que a constituição do leitor pode acontecer nas diferentes etapas da vida e atravessada pela família, escola ou universidade e, finalmente, que é basilar conscientizar os docentes da importância de se ligarem efetivamente o jovem leitor e a literatura.

Com o objetivo de discutir como a mediação pedagógica colaborativa contribui para a docência e para a aprendizagem do aluno que apresenta dificuldades em ler e escrever, Cristiane Malinoski Pianaro Angelo, Maria Andreia Batista Blum e Eliziane Manosso Streiechen, no artigo "Práticas de formação colaborativa no processo de leitura e escrita de um aluno com transtorno funcional específico", abordam a orientação a uma professora do ensino fundamental no trabalho com leitura e escrita junto ao aluno com as dificuldades. Os resultados demonstram a mudança de atitude da professora em sala de aula, a partir das atividades de formação desenvolvidas e avanços significativos do aluno em seu desenvolvimento. 
O objetivo central do ensaio "Princípios freireanos para a formação de um professor de línguas libertador" é apresentar e discutir saberes formadores docentes: criticidade; reflexão crítica sobre a prática; reconhecimento e assunção da identidade cultural; apreensão da realidade; segurança, competência profissional e generosidade; convicção de que a mudança é possível; reconhecimento que a educação é ideológica; e disponibilidade para o diálogo. Ao fim, Tainá Almeida afirma que a vida e a obra de Paulo Freire desafiam a todos os professores a construir a prática pedagógica de forma coerente, reflexiva e comprometida.

No texto "A construção da identidade cultural do professor de língua inglesa em formação inicial é analisada a construção dessa identidade em tempos de interculturalidade. Por meio de um estudo de caso de natureza etnográfica, Cremilton de Souza Santana e Diógenes Cândido de Lima exploraram a constituição da identidade do professor de línguas em formação inicial e identificou possibilidades de refletir sobre ela. Os autores finalizam afirmando que o professor de língua inglesa, ao adquirir formação nesse idioma, não perde nem sua cultura e nem sua identidade, mas aprende um novo idioma e uma nova cultura. Portanto, sua construção identitária possibilita refletir sobre os aspectos culturais e sociais da língua e tomar consciência do seu papel formador e do valor de sua cultura e identidade.

O estudo "Competências de alunos-professores: um olhar sobre a formação docente inicial em língua inglesa" de Josimayre Novelli apresenta experiências de alunas do curso de Letras com habilitação em língua inglesa, entre 1998 e 2017, visando investigar a relevância do desenvolvimento de competências do agir docente e linguístico-discursivas relacionadas à prática docente. A partir de questionários dissertativos, a autora aponta as necessidades de maior direcionamento às práticas docentes, à reflexão sobre teorias e sua aplicabilidade, ao melhoramento da supervisão dos estágios de docência. Assim, é enfatizada a relevância de um profissional formador competente, um currículo que contemple ainda mais a prática profissional docente e a formação continuada do professorformador como basilar. 
O artigo "A aula de inglês e o desmonte da educação como práxis política: um projeto de alienação do sujeito social" objetiva refletir acerca de questões educacionais e das características e implicações da realidade e prática social dos alunos da escola pública. Com base tanto no entorno escolar quanto nas aulas, Davi Gonçalves afirma que na esfera privada a educação se tornou uma mercadoria e os alunos meros clientes, na esfera pública há redirecionamentos para caminho semelhante.

Numa tônica de análise de objeto midiático, em "Você sabe o que é fake news? nunca vi e nem li, mas só ouço falar... o que são e como inter(agem) na era da pós-verdade" é abordada a noção de pós-verdade na contemporaneidade no contexto da eleição presidencial de 2018 no Brasil, quando ganhou visibilidade uma guerra híbrida, ideológica e discursiva em torno de poderes. Fundamentados na análise de discurso crítica, os autores Francisco Jeimes de Oliveira Paiva e Eduardo Dias da Silva descrevem e analisam a constituição multimodal e ideológica do discurso político da direita conservadora, reacionária e elitista brasileira, materializada na reprodução de algumas notícias falsas compartilhadas nas páginas Brasil Verde e Amarelo e Brasil, teu povo acordou. Os autores concluem que a circulação dessas fake news provocou (des)informação e manipulação de eleitores no sentido de temerem o retorno de um governo de esquerda capaz de subverter os valores conservadores e ultraliberais.

Por último, "Vidas que escrevem: processos e experiências de letramento de jovens poetas participantes do slam interescolar" apresenta experiências com a linguagem de jovens poetas participantes do movimento literário cultural slam interescolar percebendo como eles usam e atribuem sentido a sua relação com a linguagem. Na articulação entre a arte literária, os processos de letramento sociais e as culturas juvenis, Cirlene Cristina de Sousa, Priscila Lima e Silva e Andrea Lourdes Ribeiro observaram diferentes percursos linguageiros revelados em encontros e dinâmicas socializadoras, em diversos espaços. Elas concluíram que os processos formativos de letramento permitiram aos jovens pesquisados colocarem-se como autores de sua própria história ao ressignificarem os usos e significados da linguagem. 
De maneira geral, ao discorrem sobre a formação de professores de línguas, os textos evidenciam a necessidade de transformação da realidade educacional no Brasil. Seguimos nutridos pela curiosidade epistemológica (FREIRE, 1996) no exercício da reflexão permanente para a troca de saberes sobre a formação inicial e a formação continuada, acreditando que, como sujeitos, também somos professores em construção.

Esse movimento de produção de si como profissional e dos alunos-professores tem nos enredado no caminho infinito da pesquisa para tomarmos conhecimento da realidade multifacetada e mutante das sociedades globalizadas e, também, no convite à reflexão, pois

Ao se tornar pesquisadora vai se tornando capaz de encontrar/construir novas explicações para os problemas que enfrenta em seu cotidiano. Aprende a ver com outros olhos, a escutar o que antes não ouvia, a observar com atenção o que antes não percebia, a relacionar o que não lhe parecia ter qualquer relação, a testar suas intuições através de experimentos, a registrar o que observa e experimenta, a ler teoricamente a sua própria prática. (GARCIA, 1998, p. 21)

Nossa preocupação com um futuro estruturado pela equidade e pela justiça nos conduz pelas trilhas dos fundamentos teóricos e metodológicos, mas também da sensibilidade para compreender os sujeitos e suas práticas no cotidiano acadêmico e escolar. O movimento de conhecer, refletir e praticar é uma busca, antes de tudo, de conhecer a nossa realidade e nós mesmos.

Acreditamos que transformações na realidade repercutem bastante sobre a natureza das questões propostas na escola e na universidade, a maneira como aparecem e as condições para serem adequadamente respondidas. Tal movimento reflete o resultado do trabalho intelectual e, também, a maneira como os desenvolvimentos são apropriados como condição da existência para orientações do pensamento educacional. Com esse dossiê, esperamos dar ênfase à necessidade de novos diálogos entre universidade e escola, entre conhecimento acadêmico e cotidiano e a possibilidade de professores da educação 
básica também refletirem e produzirem pesquisas e teorias, em um movimento de formação permanente.

\section{REFERÊNCIAS}

CASTRO, S. T. R. Mapeando pesquisa em formação de professores de língua estrangeira em cursos de Letras na Linguística Aplicada. In: .; SILVA, E. R. (Org.). Formação do profissional docente: contribuições de pesquisas em Linguística Aplicada. Taubaté-SP: Cabral Editora; Livraria Universitária, 2006, p. 293-329.

CONTRERAS, José. Autonomia de professores. Tradução de Sandra Trabuco Valenzuela. São Paulo: Cortez, 2002.

GARCIA, C. M. Estrutura conceptual da formação de professores. In: Formação de professores: para uma mudança educativa. Lisboa: Porto Editora, 1999. p. 18-71.

GATTI, Bernardete Angelina. A formação inicial de professores para a educação básica: as licenciaturas. Revista USP, São Paulo, n. 100, p. 33-46, dez./ fev.2014. Disponível em: <http://www.revistas.usp.br/revusp/article/view/76164>. Acesso em: 12 ago. 2019.

. Formação de professores no Brasil: características e problemas. Educação e Sociedade, v. 31, n. 113, p. 1355-1379, out.-dez. 2010. Disponível em: <http://www.scielo.br/pdf/es/v31n113/16.pdf>. Acesso em: 12 ago. 2019.

FREIRE, Paulo. Pedagogia da Autonomia: saberes necessários à prática educativa. São Paulo: Paz e Terra, 1996.

LEFFA, Vilson J. Aspectos políticos da formação do professor de línguas estrangeiras. In: LEFFA, Vilson J. (Org.). O professor de linguas estrangeiras: construindo a profissão. Pelotas, 2001, v. 1, p. 333-355. Disponível em: <http://www.leffa.pro.br/textos/trabalhos/formacao.pdf.> Acesso em: 12 ago. 2019.

LIBÂNEO José C. ; PIMENTA, Selma G. Formação de profissionais da educação: Visão crítica e perspectiva de mudança. Educação e Sociedade, ano 20, n. 68, p. 239-277. dez/1999. Disponível em: <http://www.scielo.br/pdf/es/v20n68/a13v2068.pdf>. Acesso em: 12 ago. 2019.

PIMENTA, Selma Garrido. Formação de Professores: identidade e saberes da docência. In: . (Org.) Saberes Pedagógicos e Atividade Docente. São Paulo: Cortez, 2002, p. 15-34.

TARDIF, Maurice. Saberes docentes e formação profissional. Petrópolis-RJ: Vozes, 2002. 
; RAYMOND, Danielle. Saberes, tempo e aprendizagem do trabalho no magistério. Educaşão e Sociedade. v. 21, n. 73, p. 209-274, dez. 2000. Disponível em: <http://www.scielo.br/pdf/es/v21n73/4214.pdf>. Acesso em: 12 ago. 2019.

Diógenes Cândido de Lima - Uesb Janaina de Jesus Santos - Uneb Organizadores 